\title{
Episodic meteorological and nutrient-load events as drivers of coastal planktonic ecosystem dynamics: a time-series analysis
}

\author{
Òscar Guadayol ${ }^{1,2, *}$, Francesc Peters ${ }^{1}$, Cèlia Marrasée ${ }^{1}$, Josep M. Gasol ${ }^{1}$, \\ Cristina Roldán ${ }^{1}$, Elisa Berdalet ${ }^{1}$, Ramon Massana ${ }^{1}$, Anna Sabata ${ }^{1}$ \\ ${ }^{1}$ Departament de Biologia Marina i Oceanografia, Institut de Ciències del Mar, CSIC, \\ Passeig Marítim de la Barceloneta 37-49, 08003 Barcelona, Catalunya, Spain
}

${ }^{2}$ Present address: College of Oceanic and Atmospheric Sciences, Oregon State University, 104 Ocean Admin Bldg, Corvallis, Oregon 97331-5503, USA

\begin{abstract}
In temperate coastal zones, episodic meteorological forcing can have a strong impact on the classical seasonal phytoplankton succession. Episodes of continental runoff and wind storms involve nutrient enrichment and turbulence, 2 factors that can promote primary production and alter the planktonic community species composition and size structure. We determined the joint influence of these 2 variables on the osmotrophic plankton of an oligotrophic NW Mediterranean open bay. We used an 8 yr long time series of monthly physical, chemical and biological water-column parameters, and we looked for correlations between these and several meteorological and physical highfrequency time series through cross-correlation analyses. Influence of river runoff in this particular location was found to be very important for phytoplankton dynamics, whereas no immediate response of bacterioplankton was detected. Resuspension events caused by waves had a secondary importance. Cross correlations allowed defining a sequence of responses to these types of forcing, from changes in water turbidity and salinity, to increases in phytoplankton and bacteria abundances through nutrient enrichments. The maximum response of the ecosystem in terms of chlorophyll a concentration lagged nutrient enrichment events by about $1 \mathrm{wk}$. A more detailed analysis was performed between June 2003 and June 2004, a period characterised by an intense drought in summer and by 6 strong meteorological events afterwards. The increase in the frequency of meteorological events during this period drove the system from heterotrophy to autotrophy. Our data stress the importance of episodic meteorological events in coastal planktonic communities.
\end{abstract}

KEY WORDS: Episodic meteorological forcing • Coastal osmotrophic plankton • Waves . Terrestrial runoff $\cdot$ Sediment resuspension · Nutrients · Time series · NW Mediterranean

\section{INTRODUCTION}

The successional pattern of plankton populations in temperate zones is strongly determined by the seasonal nature of physical forcing (Margalef 1978). However, episodic disturbances can be of the same order of magnitude or larger than seasonal variability (e.g. Duarte et al. 1999). Therefore, these disturbances can potentially induce proportionate changes in the osmotrophic plank- tonic community, namely in bacteria and phytoplankton (e.g. Nogueira et al. 2000, Grémare et al. 2003), which are at the base of pelagic food webs and are the fastest organisms to respond to such short perturbations. Indeed, large changes in the osmotrophic community after meteorological disturbances are commonly observed (e.g. Wainright 1987, Nogueira et al. 2000).

This episodic forcing may be especially important in coastal areas, which constitute boundaries between 
3 different environments, and thus are subjected to the variability in continental, atmospheric and oceanic forcing. In particular, Mediterranean littoral systems offer a good template to study how such episodic types of forcing may alter the dynamics of the osmotrophic plankton away from the typical seasonal pattern, for 2 reasons. First, because the Mediterranean Sea is generally oligotrophic, and thus signals of allochthonous inputs may be more easily detected. Second, because one of the main characteristics of the Mediterranean climate is the irregularity of its temporal pattern of precipitation and storms (e.g. Cebrián et al. 1996).

Episodes of rainfall and wind storms are both likely to cause an input of allochthonous material into the Mediterranean coastal zone. On the one hand, sporadic heavy rainfall events often result in catastrophic terrestrial runoff, a general characteristic of the Mediterranean climate (e.g. Cebrián et al. 1996). Such cases of runoff produce unpredictable pulses in the terrestrial inputs of both inorganic and organic particulate and dissolved nutrients (Cebrián et al. 1996, Lucea et al. 2005). On the other hand, wind-driven turbulence and waves may promote sediment resuspension (Ferré et al. 2005) and/or increase the flux of dissolved nutrients from the sediment (Dade 1993). For example, the NW Mediterranean littoral is periodically assailed by severe easterly storms ('llevantades'), which, because of a long fetch, are accompanied by relatively long waves.

Thus, in the Mediterranean, torrential rainfall, as well as wind and/or high wave events, often imply an input of allochthonous material to the pelagic environment. The response of coastal osmotrophic communities to these different events may therefore be expected to show some regularities. In the first place, an almost immediate signal in biomass parameters may occur after any of these perturbations, due to the input of microorganisms either from runoff (de Madariaga et al. 1992) or from benthos resuspension (Garstecki et al. 2002). However, this signal is expected to be transient, as organisms are diluted or sink to the bottom. Another more sustained response may take place as inputs of inorganic and organic particulate and dissolved nutrients from land or sediment enhance biological production, both primary (e.g. Mura et al. 1996, Ogilvie \& Mitchell 1998) and bacterial (e.g. Wainright 1987, Grémare et al. 2003, Alonso-Sáez et al. 2008). But the increase of material in suspension also means an increase in turbidity, which may limit the light available for photosynthesis (e.g. Cloern 1987, Cotner 2000). Hence, the response may be modulated by turbidity: if the decrease in water clarity is long and intense enough to notably limit phytoplankton growth, then only bacteria will be directly favoured by nutrient input (Grémare et al. 2003). This will ultimately determine the fate of the allochthonous input, because in a system dominated by the microbial food web the organic matter exported by sedimentation may be expected to be lower, or at least slower.

Thus, we hypothesise that: (1) the signal from these episodic meteorological types of forcing may be transferred with some delay to the different components (i.e. bacteria and algae) of the coastal osmotrophic plankton community, (2) the relative importance of both turbidity and nutrient availability will determine the timing and path of this sequence, and (3) episodic perturbations may affect the osmotrophic community with such intensity as to force the whole planktonic community to temporally deviate from its typical seasonal pattern.

To explore these hypotheses, we analysed an 8 yr time series of chemical and biological parameters of the water column collected monthly at an oligotrophic coastal area (Blanes Bay, NW Mediterranean), and a set of meteorological, oceanographic and hydrological high-frequency data from the same area. We used these datasets to identify, by means of cross-correlation analyses, the sequence of responses of the available biogeochemical parameters to different types of physical forcing. Additionally, we conducted a more detailed water-column sampling between June 2003 and June 2004, which included data on size structure and specific composition of the osmotrophic planktonic community and which was used to validate and extend the conclusions drawn from the time-series analysis.

\section{MATERIALS AND METHODS}

Site. The present study was conducted in the Blanes Bay Microbial Observatory, NW Mediterranean (Fig. 1), a well-studied open and shallow oligotrophic bay with a sandy bottom and a relatively steep slope ( $2 \%$; Vaqué et al. 1997). It is located in front of the town of Blanes, which is around $70 \mathrm{~km} \mathrm{NW}$ of Barcelona, between the submarine Blanes Canyon to the north and the mouth of the La Tordera River to the south. The bay is net heterotrophic (Duarte et al. 2004) and oligotrophic, with production being limited most of the year by phosphorus (Lucea et al. 2005, Pinhassi et al. 2006). It episodically receives inputs of terrestrial runoff from the town and the surrounding coastal area. Tourism increases the population of Blanes by about 5 -fold in the summer, which potentially leads to a seasonal pattern in sewage discharge into the bay (Duarte et al. 1999) and in subsequent nutrient fertilization. However, the 2002 major upgrade of the Blanes wastewater reclamation plant allows wastewater (that was previously poured into Blanes Bay through a subsur- 


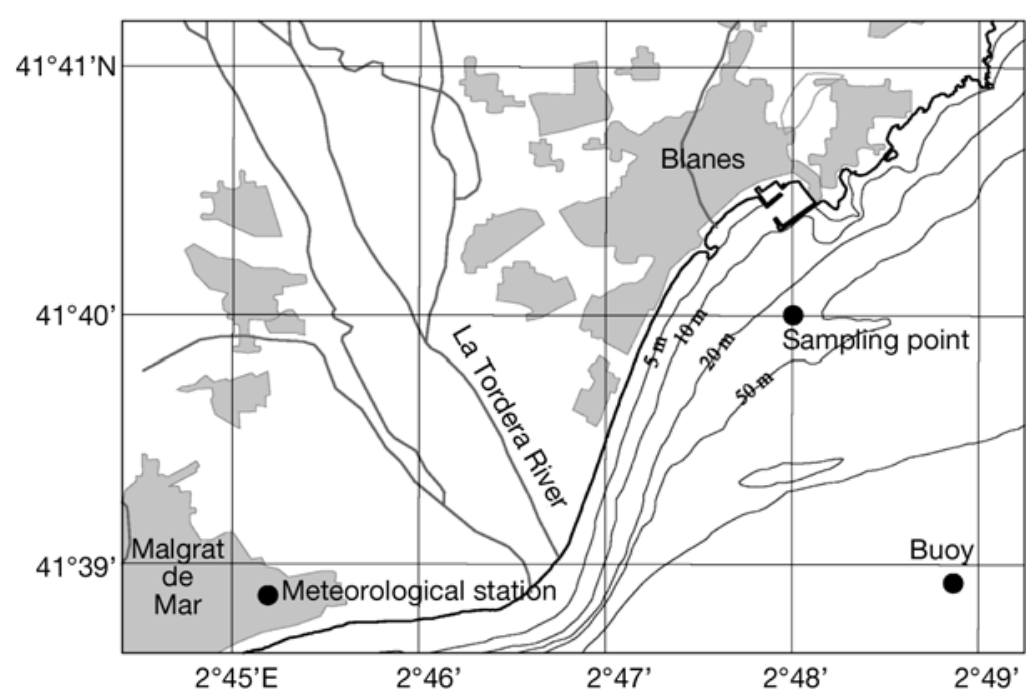

Fig. 1. Map of the studied area in Blanes Bay, NW Mediterranean Sea, showing the location of the sampling site and the data acquisition stations

$41^{\circ} 38^{\prime} 49^{\prime \prime} \mathrm{N}, 02^{\circ} 48^{\prime} 56^{\prime \prime} \mathrm{E}$ (Fig. 1), over a depth of $74 \mathrm{~m}$ (XIOM network, www. boiescat.org/). The buoy registered wave height and period. For our study, we used significant wave height (SWH), which is defined as the mean of the height (trough to crest) of the largest one-third of waves occurring during the sampling period, in this case during $1 \mathrm{~h}$.

As an estimate of terrestrial runoff (contribution of rivers and seasonal and ephemeral streams in the area), we used discharge data from the La Tordera River, which discharges south of the sampling site (Fig. 1). We used the discharge values $\left(\mathrm{m}^{3} \mathrm{~s}^{-1}\right)$ at Gauge EA89, in Fogars de la Selva, $10 \mathrm{~km}$ upstream of the mouth of the river. Data, provided by the Catalan Water Agency (http:// gencat.cat/aca), were available between October 2001 and December 2004, with a daily frequency. Some gaps in the time

face outflow pipe) to be returned into the La Tordera River. Therefore, the seasonal signal from the tourist population is now expected to be lower than before.

Meteorological and hydrological data. Meteorological data were acquired from the nearby station of Malgrat de Mar (Catalan Meteorological Service, www. meteo.cat), situated at $41^{\circ} 38^{\prime} 57^{\prime \prime} \mathrm{N}, 2^{\circ} 45^{\prime} 8^{\prime \prime} \mathrm{E}, 520 \mathrm{~m}$ from the coast (Fig. 1) and at $4 \mathrm{~m}$ above sea level. The station recorded arithmetically averaged hourly air temperature and relative humidity at $1.5 \mathrm{~m}$ above ground, vector-averaged hourly wind speed and direction and global irradiance at $2 \mathrm{~m}$, and accumulated rainfall at $1 \mathrm{~m}$. The available time-series data span $>16$ yr (from 1990 to 2007).

Wind velocity was rescaled to $10 \mathrm{~m}$ above ground assuming a logarithmic wind profile:

$$
W_{10}=W_{2} \times \log \left(10 / z_{0}\right) / \log \left(2 / z_{0}\right)
$$

where $W_{n}$ is the wind speed at $n$ metres above ground and $z_{0}$ is the aerodynamic roughness length, assumed to be $0.03 \mathrm{~m}$ (Guadayol \& Peters 2006).

The energy flux from wind forcing was calculated as:

$$
E_{\mathrm{w}}=\rho_{\mathrm{a}} C_{10} W_{10}^{3}
$$

where $\rho_{\mathrm{a}}=1.2 \mathrm{~kg} \mathrm{~m}^{-3}$ is the density of air and $C_{10}=$ $1.3 \times 10^{-3}$ is a drag coefficient (Gargett 1989). This energy flux was used as a proxy for turbulence directly generated by winds as, according to the boundary layer model (e.g. Gargett 1989), turbulent kinetic energy dissipation rates scale with energy input and distance from the input boundary (i.e. depth).

Wave data from 1997 to 2006 were obtained from a scalar buoy (DATAWELL Waverider) placed at series were filled with estimates obtained from the discharge values at Gauge EA81 (in a tributary of the La Tordera at Santa Coloma de Farners), after applying a second-degree polynomial regression model predicting EA89 from EA81 data.

Water-column parameters. Monthly subsurface water samples were taken from December 1997 to September 2006 in Blanes Bay, with a 2 yr gap in 1999 and 2000, within the framework of the Blanes Bay Microbial Observatory (Alonso-Sáez et al. 2008). Not all biogeochemical parameters used in the present study were taken uninterruptedly during the entire time series. The sampling location was about $1 \mathrm{~km}$ offshore $\left(41^{\circ} 40^{\prime} \mathrm{N}, 2^{\circ} 48^{\prime} \mathrm{E}\right)$, covering a depth of between 20 and $24 \mathrm{~m}$ (Fig. 1).

Water was taken from a depth of $0.5 \mathrm{~m}$, pre-screened with a $200 \mu \mathrm{m}$ nylon mesh to remove larger mesozooplankton and taken to the laboratory in plastic carboys within 2 h. Basic parameters included chlorophyll a (chl a) concentration, salinity, dissolved inorganic nutrients and bacterial abundance. Subsurface water temperature and Secchi disk depth, as an integrated estimate of water-column turbidity, were measured before sampling. Salinity was measured with an YSI 556 MPS Multi Probe system.

Between June 2003 and June 2004 we analysed additional parameters: particulate organic nutrients (carbon, nitrogen and phosphorus; POC, PON and POP, respectively), total nitrogen (TN) and phosphorus (TP), plastidic (PNF) and heterotrophic nanoflagellates (HNF) and microphytoplankton.

Dissolved inorganic nutrients $\left(\mathrm{NO}_{3}{ }^{-}, \mathrm{NO}_{2}{ }^{-}, \mathrm{NH}_{4}{ }^{+}\right.$, $\mathrm{PO}_{4}{ }^{3-}$ and $\mathrm{SiO}_{2}$ ) were analysed with an Alliance Evolu- 
tion II autoanalyser following the methods described by Hansen \& Koroleff (1999), with minor modifications. Samples were kept frozen at $-20^{\circ} \mathrm{C}$ until analyses.

Chl a concentration was determined fluorometrically (Yentsch \& Menzel 1963). Samples of $150 \mathrm{ml}$ were filtered through Whatman GF/F filters. Chlorophyll was extracted from filters immersed in $6.5 \mathrm{ml}$ of $90 \%$ acetone $\left(24 \mathrm{~h}\right.$ at $4{ }^{\circ} \mathrm{C}$ in the dark). The extract was analysed with a Turner Designs fluorometer.

For the determination of particulate organic matter, 200 to $500 \mathrm{ml}$ of seawater was filtered $(0.3 \mathrm{~atm})$ through pre-combusted $\left(450^{\circ} \mathrm{C}, 4 \mathrm{~h}\right)$ glass fibre filters (Whatman GF/F) that were immediately frozen in liquid nitrogen and then stored at $-80^{\circ} \mathrm{C}$. For each sample, 2 filters were processed, one for PON and POC and the other for POP. Before analysis in a Carlo-Erba $\mathrm{CHN}$ analyser, the POC/PON filters were thawed in $\mathrm{HCl}$-saturated atmosphere for $48 \mathrm{~h}$, to remove carbonates, and dried at $80^{\circ} \mathrm{C}$ for $24 \mathrm{~h}$. POP was determined following the oxidation $\left(120^{\circ} \mathrm{C}, 30 \mathrm{~min}\right)$ of the filter in acidic persulphate and subsequent colorimetric analysis of dissolved phosphate (Hansen \& Koroleff 1999).

For TP and TN analyses, water was sampled into acid-cleaned polyethylene bottles and immediately frozen $\left(-20^{\circ} \mathrm{C}\right)$. TP was determined by wet oxidation following the same procedure as for POP. TN was determined after persulphate oxidation following Hansen \& Koroleff (1999).

Abundances of bacteria and cyanobacteria (Prochlorococcus and Synechococcus) were determined by means of flow cytometry following the methods described by Gasol \& del Giorgio (2000), using a Becton Dickinson FACSCalibur bench cytometer with a laser emitting at $488 \mathrm{~nm}$. To count heterotrophic bacteria, $200 \mu \mathrm{l}$ was stained with a DMSO-diluted Syto13 (Molecular Probes) at $2.5 \mu \mathrm{M}$ final concentration, left for at least 10 min in the dark to complete the staining, and run in the flow cytometer at a low flow rate (between ca. 10 and $50 \mu \mathrm{l} \mathrm{min}{ }^{-1}$ ) for $2 \mathrm{~min}$. For cyanobacterial counts, nonstained $200 \mu \mathrm{l}$ subsamples were run at a high flow rate (between ca. 60 and $80 \mu \mathrm{lmin}^{-1}$ ) for $5 \mathrm{~min}$. Abundances were determined using flow speed, which was calibrated every 10 samples by measuring sample volume before and after a $10 \mathrm{~min}$ run. In all cases, $10 \mu \mathrm{sample}^{-1}$ of a solution of yellow-green, $1 \mu \mathrm{m}$ Polysciences latex beads $\left(10^{6}\right.$ beads $\left.\mathrm{ml}^{-1}\right)$ were added as a fluorescence standard. Bacterial average cell volume was estimated with the calibration function provided by Gasol \& del Giorgio (2000):

$$
B=7.5 \times 10^{-3}+1.1 \times 10^{-1}\left(\frac{F_{\text {bacteria }}}{F_{\text {beads }}}\right)
$$

where $B$ is the average volume of bacteria in cubic micrometres, $F_{\text {bacteria }}$ is the mean green fluorescence of bacteria, and $F_{\text {beads }}$ is mean green fluorescence of the beads.
Average volume for cyanobacteria was estimated assuming a spherical shape. We considered a diameter of $1 \mu \mathrm{m}$ for Synechococcus sp. (Agawin et al. 1998) and of $0.7 \mu \mathrm{m}$ for Prochlorococcus sp. (Vaulot et al. 1990).

Subsamples for HNF and PNF were fixed with 1.5\% (final concentration) glutaraldehyde, stained with DAPI (4', 6'diamidino-2-phenylindole) at $5 \mu \mathrm{g} \mathrm{ml}^{-1}$, and filtered through $0.8 \mu \mathrm{m}$ black polycarbonate membranes. Filters were mounted on slides and stored at $-20^{\circ} \mathrm{C}$ before counting by epifluorescence microscopy. Per filter, 150 to 250 flagellates were counted and classified in 4 size classes: $<4,4$ to 8,8 to 16 and $>16 \mu \mathrm{m}$ in diameter. Cellular volume was estimated from the mean size of each class assuming a spherical shape. For the $<4 \mu \mathrm{m}$ size class, an average diameter of $3 \mu \mathrm{m}$ was used. Plastidic flagellates were distinguished from heterotrophic flagellates by the fluorescence of chl a detected under blue light.

Microphytoplankton were identified and counted with an inverted microscope using the Utermöhl technique. Briefly, $60 \mathrm{ml}$ samples were fixed with formalinhexamine $\left(0.4 \%\right.$ final concentration) and kept at $4{ }^{\circ} \mathrm{C}$ until analysis. Aliquots of 12 to $50 \mathrm{ml}$ were transferred to sedimentation chambers and left undisturbed for $24 \mathrm{~h}$. The sedimentation chamber was scanned in the inverted microscope at $100 \times$ and $400 \times$ magnifications. Dominant phytoplankton were identified at least to genus level. Width and length of cells were measured for each cell or for each colony or chain. The number of cells per aggregate was also counted. When possible, the volume of each cell was calculated applying the formula provided by Hillebrand et al. (1999). In radially asymmetrical cells the closest 2-parameter geometrical shape was assumed. This may cause certain bias in the estimation of biovolumes, especially when radially asymmetrical cells are dominant.

Calculations and statistical analyses. Correlations between parameters were performed using Pearson's correlation coefficient $\left(r_{p}\right)$. When the number of samples was low (i.e. $\mathrm{n}<25$ ) correlations between parameters were estimated using non-parametric Spearman's correlation coefficient $\left(\mathrm{r}_{\mathrm{s}}\right)$. When performing multiple tests, resulting individual $\mathrm{p}$-values were adjusted by controlling for false discovery rate (Benjamini \& Hochberg 1995).

Several tests were applied to the meteorological and hydrological time series in order to determine if any detrending or deseasonal filters were needed before conducting cross-correlation analyses. First, autocorrelation functions (data not shown) revealed that only air temperature had a strong seasonal signal, whereas SWH showed a very mild one. Wind energy flux, precipitation and river discharge showed flat autocorrelation functions. Thus, no filter was applied to remove seasonal signals before cross-correlation analyses. On the other hand, daily variability and high-frequency noise were 
filtered out with a $7 \mathrm{~d}$ moving average. No obvious trend was apparent in any of the time series, and thus no detrending filter was applied.

Cross correlations were systematically performed between the $7 \mathrm{~d}$ moving-averaged physical data, on the one hand, and water sampling data, on the other. A cross correlation is a standard method to estimate the degree of covariation of 2 time series, as a function of the time lag between them (e.g. Jenkins \& Watts 1968). By plotting the correlation coefficients versus the time lag (cross correlogram), it is possible to identify the time scales of response of one variable with respect to another. Usually, when performing this type of analysis, the sampling frequency of the 2 series is the same to avoid the appearance of spurious signals. In order to retain information contained in the short-term physical parameters, we cross correlated the monthly sampled parameters with the original high-frequency physical data series (Chatellier \& Fitzpatrick 2005). For example, for a lag of $10 \mathrm{~d}$, we computed the correlation coefficient between our monthly water sampling measurements and the respective values of the high-frequency parameters $10 \mathrm{~d}$ before each sampling. This decreases robustness of the analysis, but allows detection of responses on a weekly scale.

As both the different meteorological and hydrodynamical time series and the different parameters of the Blanes Bay Microbial Observatory had different time spans and missing points, the number of samples in each cross correlation was different.

Osmotrophic plankton biomass-size spectra were calculated from data on concentration and volume of phytoplankton and bacterioplankton assuming a Pareto Type I distribution (Vidondo et al. 1997). One of the parameters of this statistical frequency distribution, the parameter $C$, is equivalent to the negative slope of the normalised biomass-size spectrum. In a normalised biomass-size spectrum, particles (i.e. cells, chains, aggregates, etc.) are grouped in logarithmic size classes and the density of each class, i.e. the normalised biomass, is plotted against the size. The slope of such a spectrum gives relevant information about the size structure of a particular community. For example, communities dominated by small organisms have slopes steeper than those dominated by large organisms. In the present case, in order to apply the Pareto I adjustment proposed by Vidondo et al. (1997), the free-living cells and the aggregates or colonies were used as basic items. For plastidic flagellates $<16 \mu \mathrm{m}$ in diameter, epifluorescence microscopy counts were used, whereas, for larger flagellates, Utermöhl counts were used.

Carbon content of bacteria was estimated using a conversion factor of $0.35 \mathrm{pg} \mathrm{C} \mathrm{\mu m}^{-3}$ (Bjørnsen 1986). Prochlorococcus sp. was estimated using a conversion factor of $0.226 \mathrm{pg} \mathrm{C} \mathrm{m}^{-3}$ (Bertilsson et al. 2003). For Syne- chococcus sp., we used a mean carbon content of 0.265 pg C $\mathrm{mm}^{-3}$ (Bertilsson et al. 2003). Carbon content of microphytoplankton was estimated applying the formula $C=0.109 V^{0.991}$ (Montagnes et al. 1994), where $C$ is the carbon content in picograms per cell and $V$ is the biovolume in micrometres per cell. Similarly, for PNF, we used the formula $C=0.433 V^{0.863}$ (Verity et al. 1992).

\section{RESULTS}

\section{Climatology}

Air temperature is the meteorological parameter with the strongest seasonality (Fig. 2A). Wind energy flux in the studied area is at a maximum in the spring, between April and May, and at a minimum in the summer and autumn (Fig. 2B), a pattern strongly determined by local topography. During autumn, wind energy flux is relatively low if compared with the general situation on the Catalan coast, where autumn is the season with the highest frequency of wind events (Guadayol \& Peters 2006). However, the frequency of intense storms is still highest during autumn in the area. Most of the year, the prevailing winds in Blanes are south-westerlies (locally called 'garbins'). These moderate, typical of summer, winds originate as strong south-eastern sea breezes that are subsequently modified by the Coriolis effect. Offshore winds, mostly north-westerlies, prevail only in autumn, although they are also very frequent in winter. The eastern and north-eastern winds ('llevant') are not very frequent, but can be strong, and because of a potentially long fetch, can be associated with high waves. Storms with easterly winds usually occur when there is a low pressure system in the SW Mediterranean and are usually accompanied by persistent rains (Reiter 1975).

SWH tends to be slightly higher in autumn than in the rest of the year (Fig. 2C). However, high-frequency variability is more important than seasonality.

Precipitation (Fig. 2D) follows the classical pattern for the Mediterranean climate (e.g. Llasat \& Puigcerver 1997), i.e. episodic and strong rainstorms in spring and autumn and dry summers. River discharge clearly follows the dynamics of precipitation (Fig. 2E), although a seasonal pattern could not be established because the time series was not long enough $(<4$ yr).

\section{Water-column parameters}

Surface water temperature (Fig. 3A) is closely linked to air temperature (Fig. 2A) and shows a marked seasonality. It has a seasonal maximum at around $25^{\circ} \mathrm{C}$ between August and September, and a seasonal mini- 


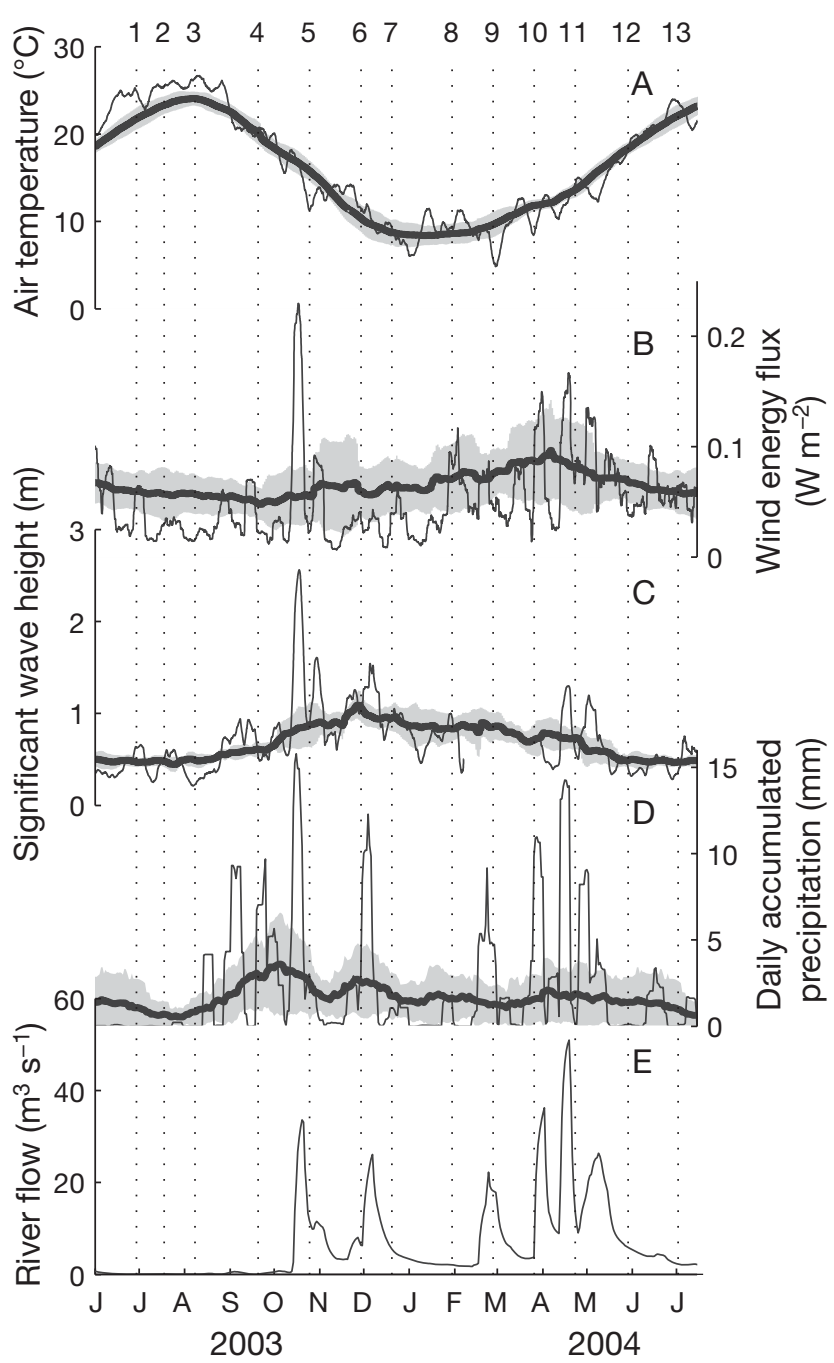

Fig. 2. Seasonal dynamics of air temperature (A), wind energy flux (B), significant wave height (C) and accumulated precipitation (D) in Blanes Bay, and river discharge (E) at Stn EA89 in the La Tordera River. A seasonal component for meteorological parameters (air temperature, wind and precipitation) and significant wave height was computed as the average (thick line) and standard deviation (grey area) for each day of the year after smoothing with a $30 \mathrm{~d}$ moving average. For the river discharge, the seasonal component was not computed because the time series was not long enough (from October 2001 to April 2005, <4 yr). Meteorological parameters were available from February 1990 to June 2007. Buoy data were available from January 1997 to September 2006. The thin lines show the $7 \mathrm{~d}$ moving-averaged values for the period between June 2003 and June 2004. Vertical discontinuous bars mark the times of water-column samplings during this period and are sequentially numbered at the top of the figure

mum of around $12^{\circ} \mathrm{C}$ between February and March. Salinity (Fig. 3B) ranges between 36.0 and 38.7 (practical salinity scale), with no clear seasonality. Secchi disk depth (Fig. 3C) ranges between $3.5 \mathrm{~m}$ and the whole water-column depth (20 to $24 \mathrm{~m}$ ). In general, trans-

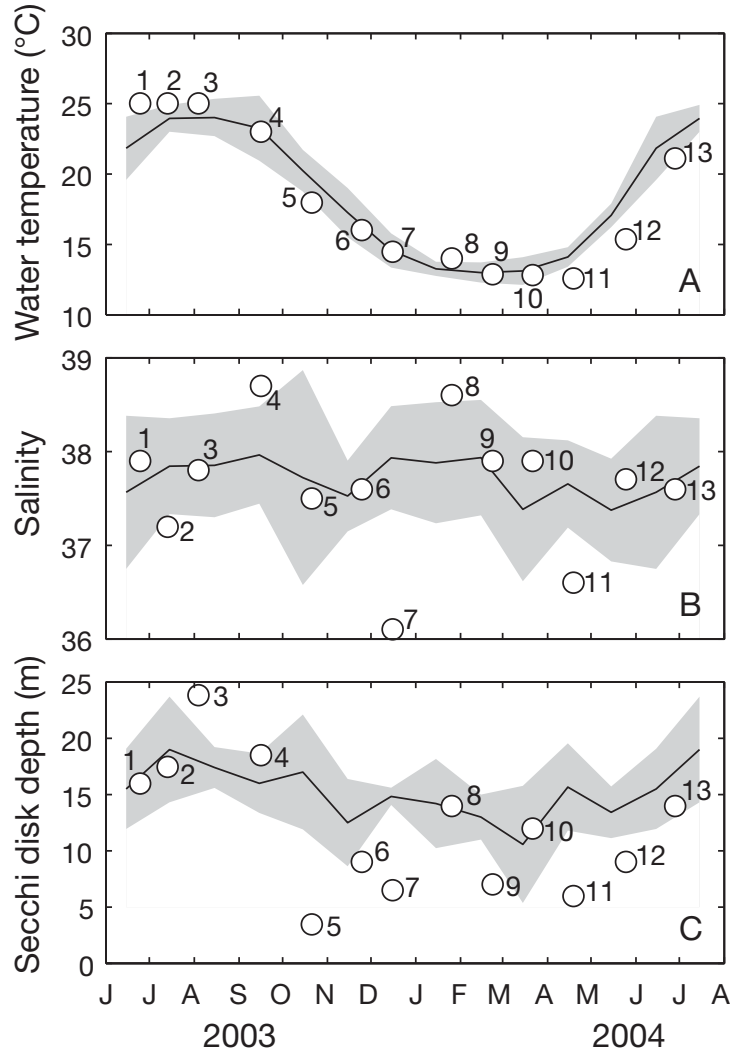

Fig. 3. Water temperature (A), salinity (B) and Secchi disk depths $(C)$ in Blanes Bay. Thin lines and grey areas show average values and standard deviations, respectively, calculated for each month of the year, using all available data from December 1997 to September 2006 (see 'Materials and methods'), excluding the values from the period between June 2003 and June 2004. Open circles: values for the period between June

2003 and June 2004, labelled in the order of sampling

parency is higher in summer, although no obvious seasonality was observed. Chl a (Fig. 4A) exhibits a typical seasonal pattern for this area (Estrada et al. 1985, Mura et al. 1996), with a main peak occurring between late winter and spring (broadly coinciding with the maximum wind energy flux), minimum concentrations in summer, and a secondary peak in autumn. Bacterial abundance (Fig. 4B) shows no clear seasonality.

Secchi disk depth and chl a were significantly correlated with water temperature (Table 1), indicating their seasonal dynamics. Dissolved inorganic nutrients, except ammonium and phosphate, also correlated significantly with water temperature (Table 1).

\section{Cross correlations}

Cross correlograms were performed between the available meteorological and hydrological variables (i.e. air temperature, wind energy flux, SWH, rainfall and river discharge) and the biogeochemical water- 

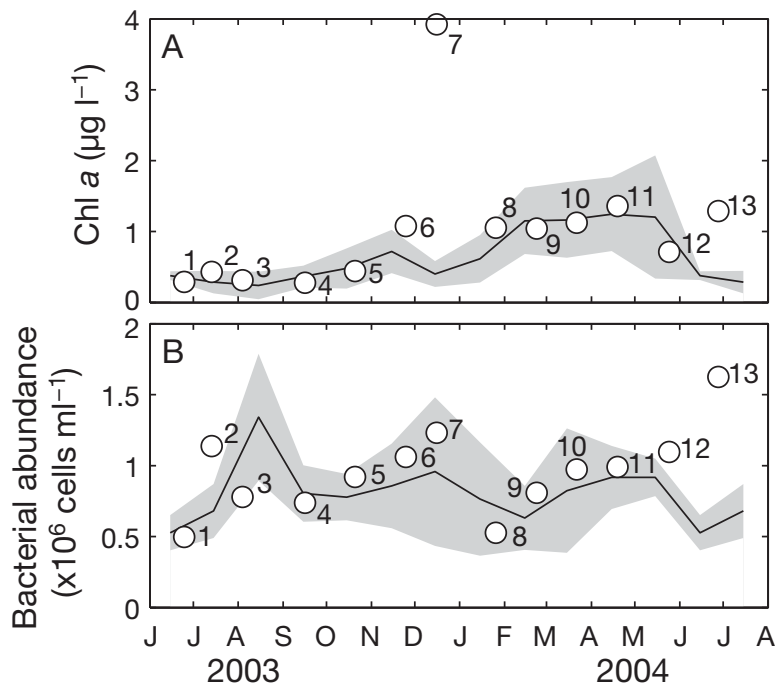

Fig. 4. Chlorophyll a (chl a) concentration (A) and bacterial abundance (B). Thin lines and grey areas show average values and standard deviations, respectively, calculated for each month of the year, using all available data from December 1997 to September 2006 (see 'Materials and methods'), excluding values from the period between June 2003 and June 2004. Open circles: values for the period between June 2003 and June 2004, labelled in the order of sampling

column parameters. Only SWH (Fig. 5), rainfall (not shown) and river discharge (Fig. 6) resulted in peaks of significant correlations with relatively short lags (i.e. $<30$ d). Rainfall cross correlograms are not shown as they were very similar to those of river discharge, with slightly longer time responses and lower correlation levels. Air temperature was significantly correlated with several of the parameters, although the patterns were not spiky, but rather constant for several months, implying a seasonal relationship. Wind energy flux showed no significant relationship with any of the water-column parameters. Note that the number of data points included in each cross correlation was different (Figs. $5 \& 6$ ). This is because the time span differed for each parameter. For each cross correlation, the maximum possible number of values was used.

Salinity and Secchi depth were both negatively correlated with river discharge (Fig. 6). Water temperature was also negatively correlated, but did not show a short-lag pattern, indicating a seasonal relationship with river discharge. $\mathrm{NO}_{3}{ }^{-}$and $\mathrm{SiO}_{2}$ had positive correlations with river discharge, whereas $\mathrm{PO}_{4}{ }^{3-}$ showed no response. Chl a concentration and $\mathrm{NO}_{2}{ }^{-}$showed similar patterns, with a delayed response with respect to the other parameters. Chl a showed the highest maximum correlations with river discharge (with a 11 d lag, $r_{p}>0.9, p<0.0001, n=31$ ). Bacterial abundance had the most delayed and weakest response to river input.

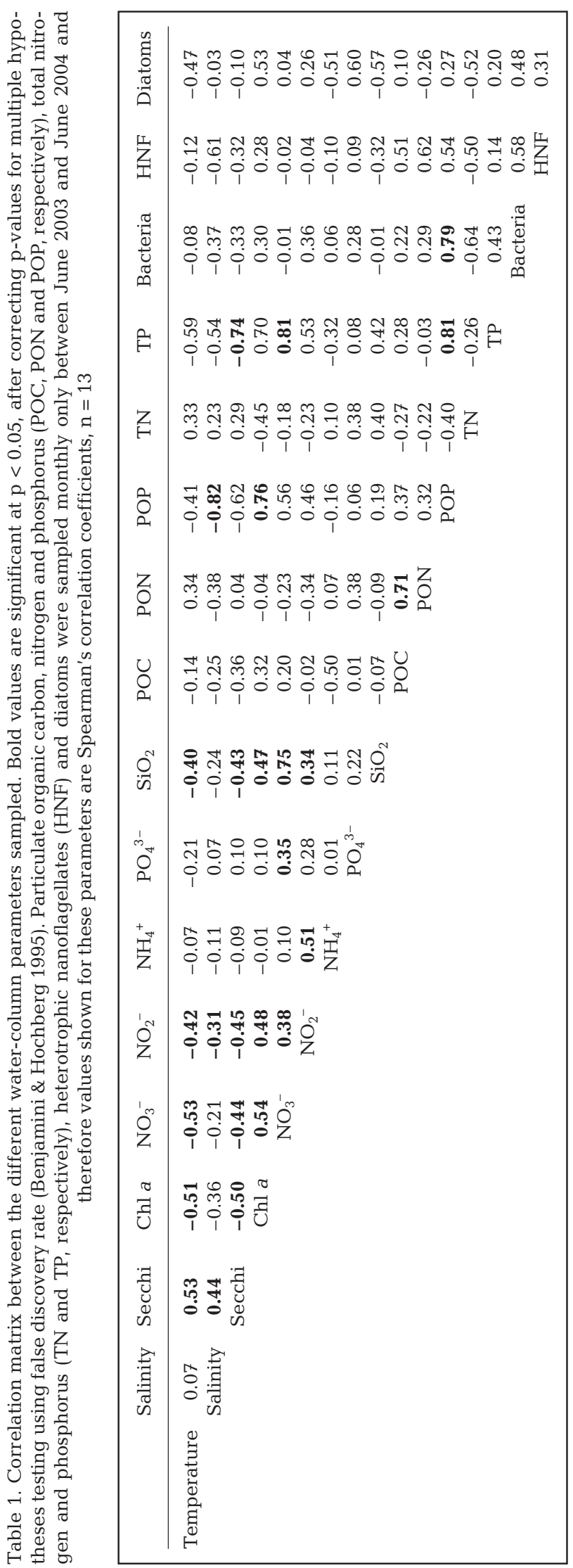



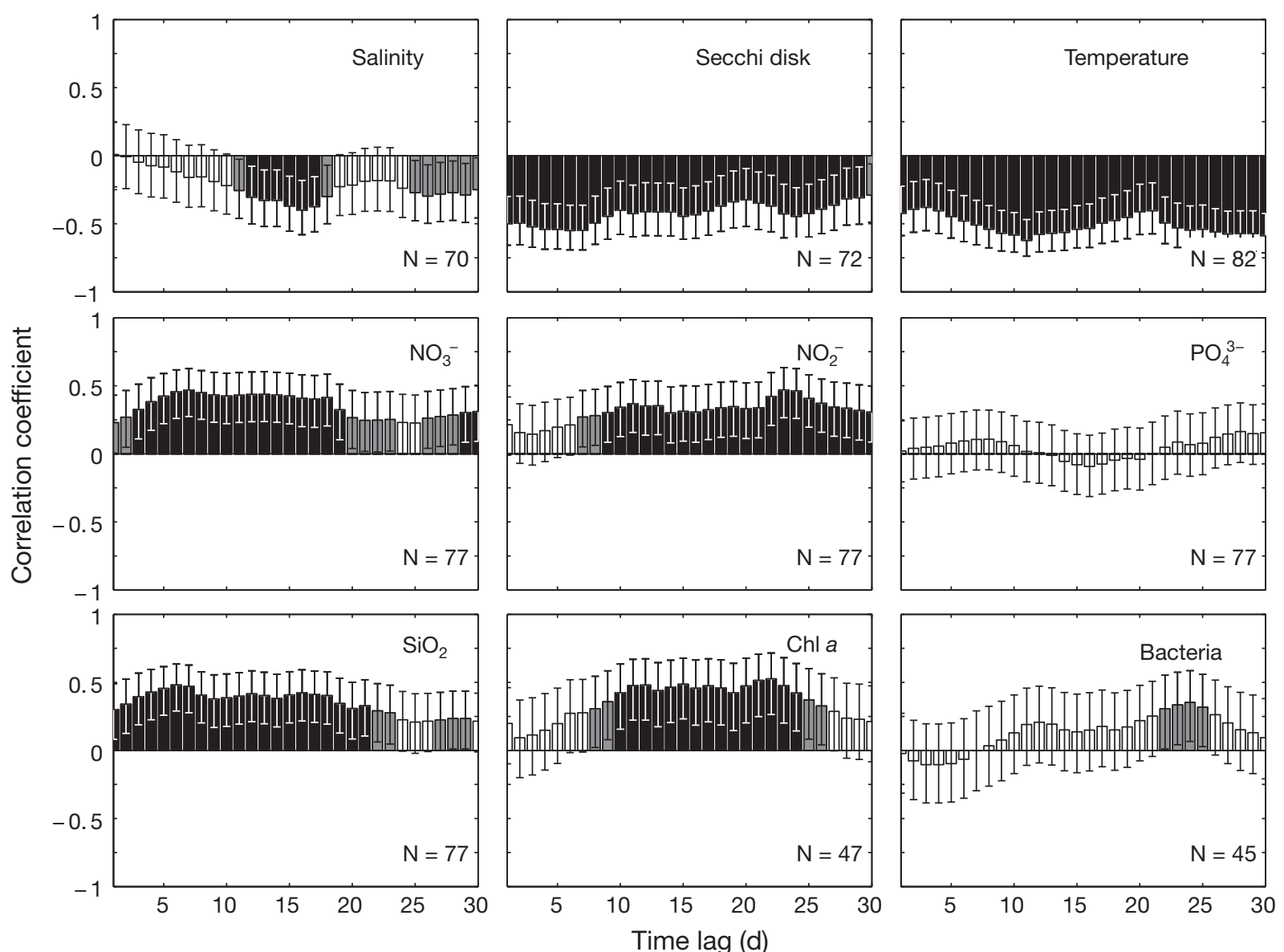

Fig. 5. Cross correlograms between significant wave height (SWH) and water-column parameters. Black bars represent correlation coefficients at a significant level of $\mathrm{p}<0.01$, grey bars are significant at $\mathrm{p}<0.05$ and open bars are non-significant. Error bars are confidence intervals at $95 \%$

Cross correlograms with SWH (Fig. 5) showed similar patterns to those with river discharge, although correlation coefficients were lower, and the time responses were in general longer and weaker. Secchi depth, $\mathrm{NO}_{3}{ }^{-}$and $\mathrm{SiO}_{2}$ were significantly correlated with $\mathrm{SWH}$ at lag 0, whereas salinity response was more delayed.

\section{June 2003 to June 2004 period}

Between June 2003 and June 2004 a detailed analysis, which included several additional parameters with respect to the basic sampling, was performed. During this period there were 6 major meteorological events, 2 of them in the autumn of 2003 and the others in the spring of 2004 (Fig. 2). The meteorological events were identified as peaks in $\mathrm{SWH}$, river flow and precipitation (except for the events occurring between February and March 2004, when there was a gap in SWH data). Not all these events matched a peak in wind energy flux, suggesting that, in some cases, local wind did not play a major role and that high values of SWH were the result of swell. For example, the event in December 2003 did not show any peaks in wind energy flux, regardless of the event in SWH. On the other hand, in November 2006, the peak in SWH showed no correspondence in precipitation or river flow. In each one of the identified events, the signals in daily accumulated precipitation and SWH were simultaneous, and preceded the peak in river flow by several days. The signals in river flow decayed more smoothly than the meteorological signals.

Air temperature in the summer of 2003 was anomalously high (Fig. 2A; Trenberth et al. 2007), although this was only reflected in a very slight positive anomaly in water temperatures (Fig. 3A). Summer was also characterised by low wind energy fluxes and almost no river discharge (Fig. 2B,E). The water column was mixed for most of the year. Only in the summer, between June and September, did a shallow thermocline at 2 to $3 \mathrm{~m}$ form (Vila-Costa et al. 2007). The 6 minimum Secchi disk depths occurred in samplings performed within $3 \mathrm{wk}$ after meteorological events, 

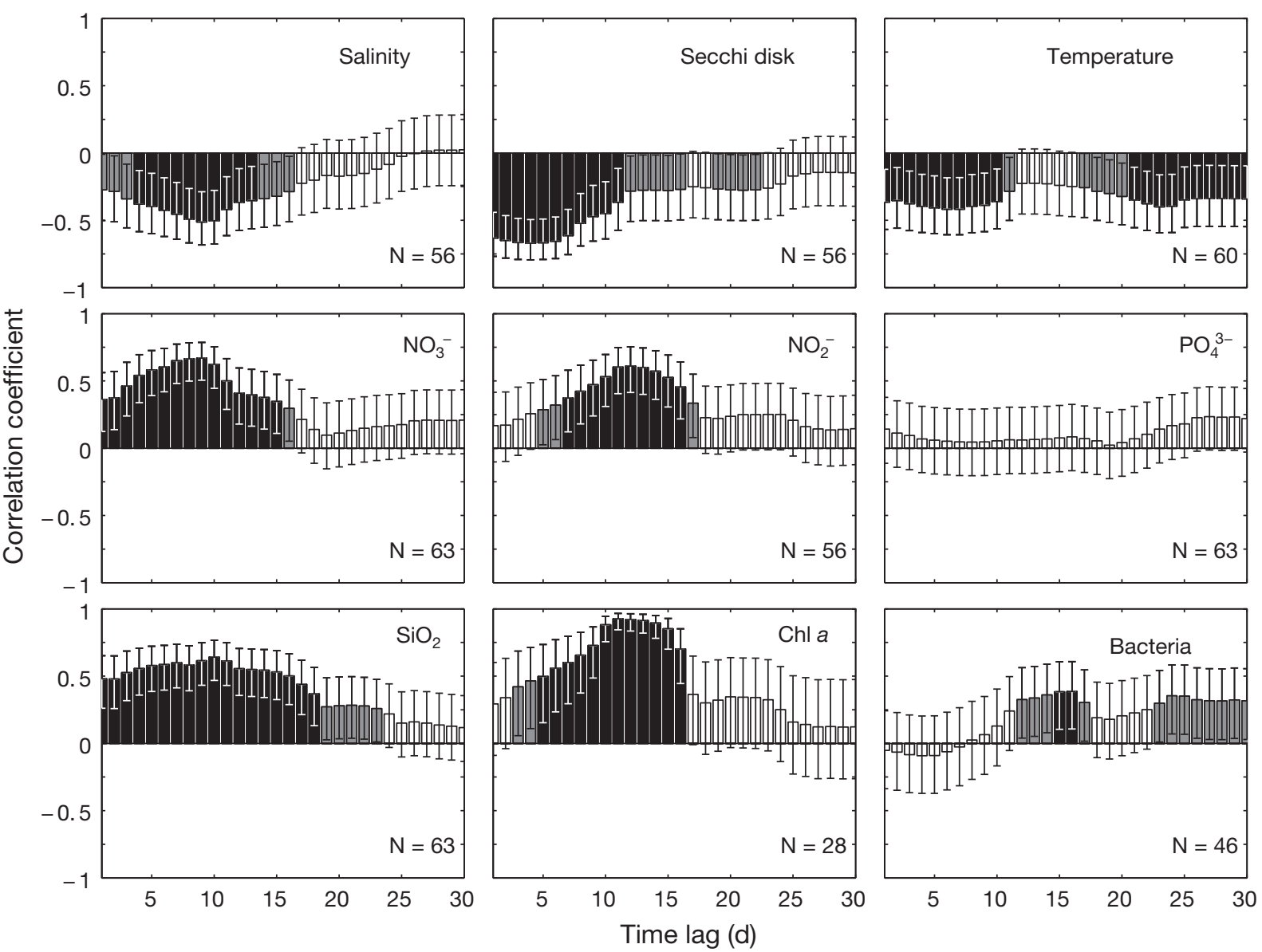

Fig. 6. Cross correlograms between the river discharge and the sampled water-column parameters. Black bars represent correlation coefficients at a significant level of $p<0.01$, grey bars are significant at $p<0.05$ and open bars are non-significant. Error bars are confidence intervals at $95 \%$

except for the November 2003 sampling, which was done almost a month after an isolated SWH peak. Salinity minima were measured in the samplings after the meteorological events in December 2003 and April 2004.

Silicate and nitrate were strongly coincident during this period (Fig. 7), as well as for the whole dataset (Table 1). Both presented 3 local maxima in October, December and April, after 4 major meteorological events. Silicate concentration decayed to its minimum concentrations in the last 2 samplings. Nitrite followed the same pattern as the chl a concentration. Ammonia was low during the whole year, ranging between 0.06 and $0.48 \mu \mathrm{mol} \mathrm{l^{-1 }}$. However, during the first part of the period, when mean river runoff and wind energy flux were low, $\mathrm{NH}_{4}{ }^{+}$was significantly higher. By contrast, phosphate concentration was low $\left(<0.03 \mu \mathrm{mol} \mathrm{l}^{-1}\right)$ in the summer of 2003 , and then it tended to increase to reach values $>0.2 \mu \mathrm{mol} \mathrm{l^{-1 }}$ by the end of the period. No local maxima after the meteorological events were observed in $\mathrm{PO}_{4}{ }^{3-}$ or in $\mathrm{NH}_{4}{ }^{+}$concentrations.
Within the period of the detailed study, chl a (Fig. 4A) ranged from ca. 0.30 to $3.93 \mu \mathrm{g} \mathrm{l}^{-1}$. Between June and September 2003, chl a was typically low. The maximum concentration was found in December 2003, following an event that took place 2 wk before (Fig. 2) and coinciding with the minimum surface salinity, which also indicates an intrusion of freshwater from the river or from terrestrial runoff.

Bacterial abundance within the period varied between $5.0 \times 10^{5}$ and $1.6 \times 10^{6}$ cells ml $^{-1}$ (Fig. 4B). HNF abundances (data not shown) were between $7.3 \times 10^{2}$ and $3.1 \times 10^{3}$ cells $\mathrm{ml}^{-1}$. Both variables were positively correlated between June 2003 and February $2004\left(\mathrm{r}_{\mathrm{s}}=\right.$ $0.82, \mathrm{p}=0.011, \mathrm{n}=9$ ). However, when considering the whole period, correlation was not significant (Table 1).

Phytoplankton composition is shown in Fig. 8A. The concentration of Synechococcus sp. ranged between $1.4 \times 10^{3}$ and $7.1 \times 10^{4}$ cells $\mathrm{ml}^{-1}$, with a maximum in summer. Prochlorococcus sp. appeared after the Synechococcus sp. peak and lasted throughout the autumn and winter, with a maximum in December 2003. PNF also peaked in December 2003, coinciding with the 


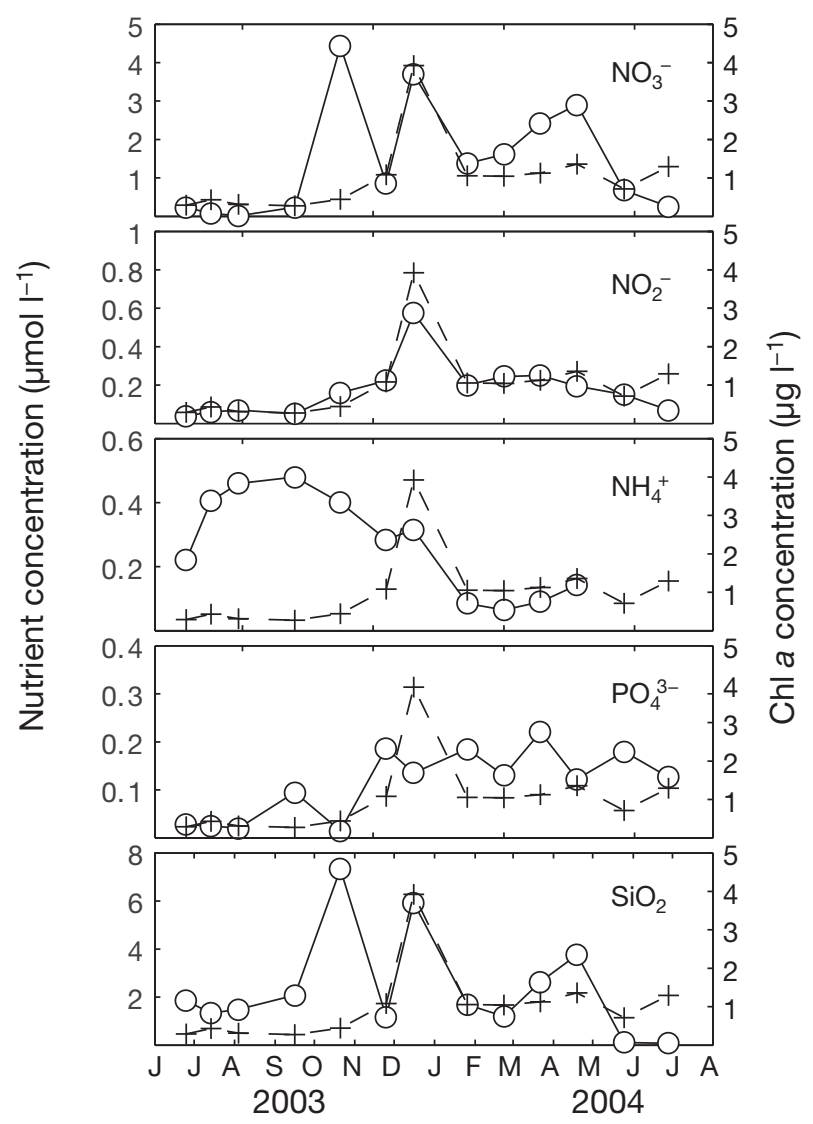

Fig. 7. Nutrient concentrations (O) in Blanes Bay between June 2003 and June 2004. The chl a concentration (+) is represented in each subplot for reference

chl a peak, and then showed a smaller maximum in March 2004. The abundances ranged between $1.2 \times$ $10^{3}$ and $3.2 \times 10^{4}$ cells ml ${ }^{-1}$. Diatoms tended to increase throughout this period. In the first 4 samplings they were relatively low. After the first major meteorological event in October 2003, diatoms became dominant in the phytoplanktonic community in terms of biomass. Maximum abundances were reached at the end of the period, in May and June 2004, due to the great abundance of Chaetoceros spp. chains. In these months the silicate concentration was at a minimum.

Between June and August 2003 the slope of the size spectra (equivalent to the $c$ parameter of the Pareto statistical distribution; Vidondo et al. 1997) of the osmotrophic community was highest (Fig. 8B). Phytoplankton was dominated by the smallest organisms, i.e. cyanobacteria and PNF $<16 \mu \mathrm{m}$, and the contribution of diatoms in terms of carbon was ca. 10\%. In September, the slope noticeably decreased as coccolithophores $>16 \mu \mathrm{m}$ increased in abundance. For the rest of the period, from October 2003 to June 2004, diatoms were clearly dominant, with the exception of the sampling in December, after the second meteoro- logical event, when there was a peak in PNF along with an increase in the slope of the size spectrum. In the last $3 \mathrm{mo}$, the slope was low, due to an increase in diatom concentration, mainly Chaetoceros spp. The living phytoplanktonic C:chl ratio was between 20 and 60, except for December 2003, when it was around 10, and for May and June 2004, coinciding with the bloom of Chaetoceros spp., when it was $>100$.

\section{DISCUSSION}

\section{Sequence of responses}

Cross correlations are a common tool in ecology to investigate lags in responses between different variables (e.g. Olden \& Neff 2001). In our study, the frequency of biogeochemical sampling was not high enough to perform cross correlations between different water-column parameters. However, it was possible to establish their sequence of response to physical forcing from their cross correlations with highfrequency meteorological and hydrological time series. The high-frequency time series used in these analyses were air temperature, precipitation, wind energy flux, SWH and river discharge. The water-column parameters with a marked seasonal variability, such as chl a or Secchi depth (Table 1), were significantly correlated with air temperature. In accordance with this, the cross correlograms with air temperature (data not shown) presented low-frequency oscillations, with periods of several months, indicating seasonal relationships. By contrast, the patterns observed with SWH, precipitation and river discharge, which are parameters characterised by high variability over short time scales (Duarte et al. 1999), were completely different. Cross correlations (Figs. $5 \& 6$ ) showed distinct and highly significant peaks with short time lags, on the order of days, suggesting rapid responses to episodic events.

The highest correlations were found with river discharge (Fig. 6). Correlations with SWH (Fig. 5) and particularly with precipitation showed remarkable resemblance to those with river discharge, but with slightly longer delays. In fact, SWH and river discharge were significantly cross-correlated, with a maximum at a $3 \mathrm{~d}$ lag (not shown). In the NW Mediterranean, rough seas often coincided with torrential rains during strong easterly storms (Arnau et al. 2004).

Based on the cross correlations with the episodically forcing parameters (i.e. SWH, precipitation and river discharge), we propose the sequence of responses to meteorological events can be explained as illustrated in Fig. 9. Secchi depth, which can be considered an integrated estimate of water-column turbidity, decreases immediately after a meteorological event. This is a 


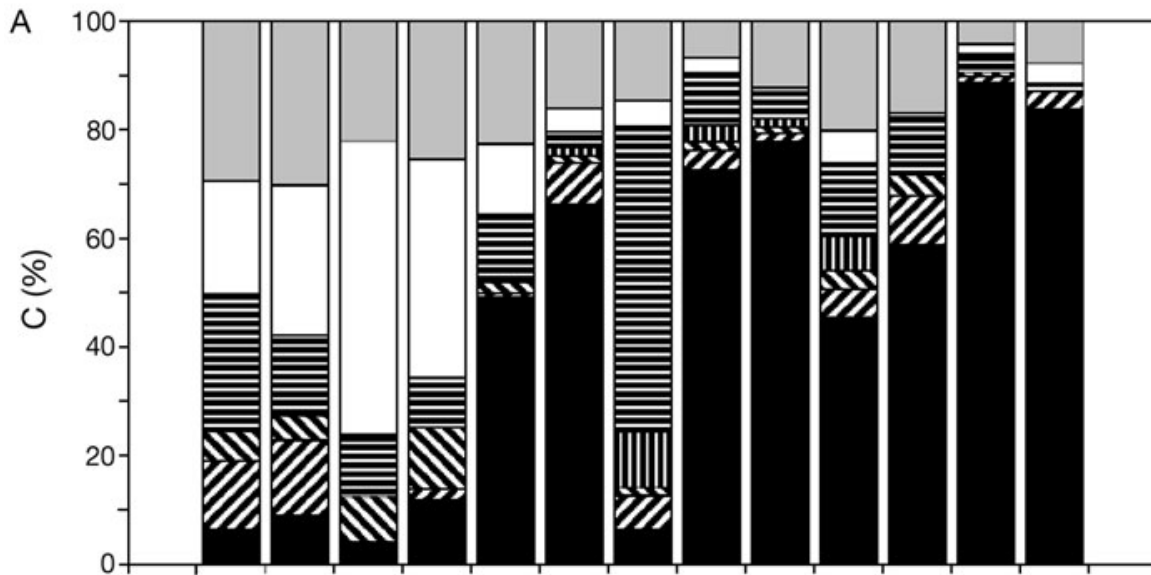

B

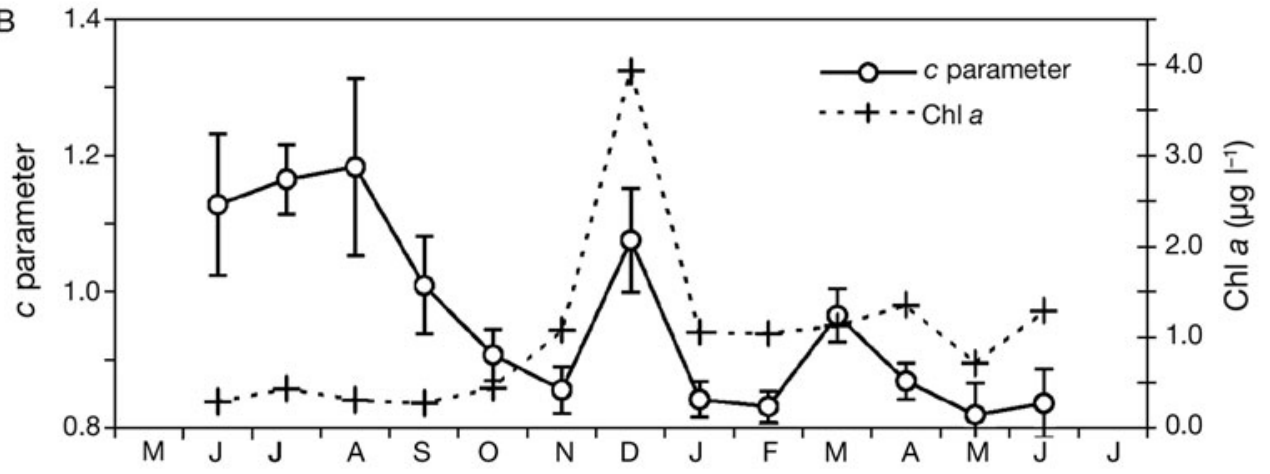

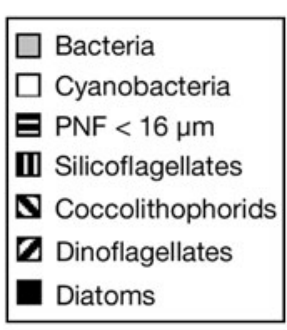

Fig. 8. (A) Percentage contribution of each of the main phytoplanktonic groups to total phytoplankton carbon between June 2003 and June 2004. (B) Slopes of the osmotrophic biomass-size spectra (calculated as the $c$ parameter of the adjusted Pareto distribution; Vidondo et al. 1997). The chl a concentration ( + ) is represented for reference. Cyanobacteria include Prochlorococcus spp. and Synechococcus spp. PNF: plastidic nanoflagellates common observation in response to storms and can be explained by the increase in suspended material either by resuspension of sediments (Cloern 1987, Cotner 2000) or by the input of organic material from terrestrial runoff (Cloern 1987). Next, a decrease in surface salinity is observed, which must be attributed to the arrival of freshwater from terrestrial runoff (e.g. Cloern 1996). The relatively long lag in correlation between river discharge and salinity may be due, in part, to the fact that the discharge gauge is located somewhat upstream (ca. $10 \mathrm{~km}$ ). More likely, the salinity signal takes some days to diffuse into the sampling location, as river flow in the La Tordera River may be considered as an estimate of terrestrial runoff in the whole area.

On the other hand, $\mathrm{NO}_{3}{ }^{-}$and $\mathrm{SiO}_{2}$ correlations are significant without a time lag (i.e. lag $=0$ ). In the case of river flow, however, distinctive positive peaks occur at the same time as the salinity minimum and after the maximum in Secchi disk correlation. This positive response can be attributed to the input from terrestrial runoff and/or from sediment resuspension (Fig. 9). No simultaneous signal, due to the hypothetical input of allochthonous organisms either from benthos resuspension or from terrestrial runoff, was detected in biomass parameters. However, with a few days lag, biomass of autotrophic organisms responds to this increase in inorganic nutrient concentration. This lag is within the same range found by Duarte et al. (2000) in a mesocosm experiment conducted in Blanes Bay during July. They found a lag of between 4 and $12 \mathrm{~d}$ in the response of chl a to nutrient additions, depending on the level of nutrient enrichment. The delay in the response to nutrient input could, in part, be explained by an initial negative effect on primary production of the limited light availability as a consequence of increased turbidity (Cloern 1987, Cotner 2000). The negative correlations found with Secchi disk depths support this scenario. However, in the experimental setup in Duarte et al. (2000), there was no increase in turbidity as the nutrients were added without extra additions. Thus, the delay could be explained entirely by a relatively slow response of phytoplankton.

Along with the peak in chl a correlation to river discharge, we observed a very similar peak in $\mathrm{NO}_{2}^{-}$. Furthermore, both parameters were strongly correlated (Table 1). Nitrite is excreted from cells under growthlimiting conditions (e.g. when light is low; Collos 1998), because its further reduction to ammonia needs energy, and presumably because of its toxicity (Lomas \& Lipschultz 2006). This co-variation is evidence that $\mathrm{N}$ is not the dominant limiting element in Blanes Bay, as in N-limiting conditions nitrite is expected to be significantly taken up by phytoplankton (Collos 1998). P-limitation seems to be a more general situation, since 


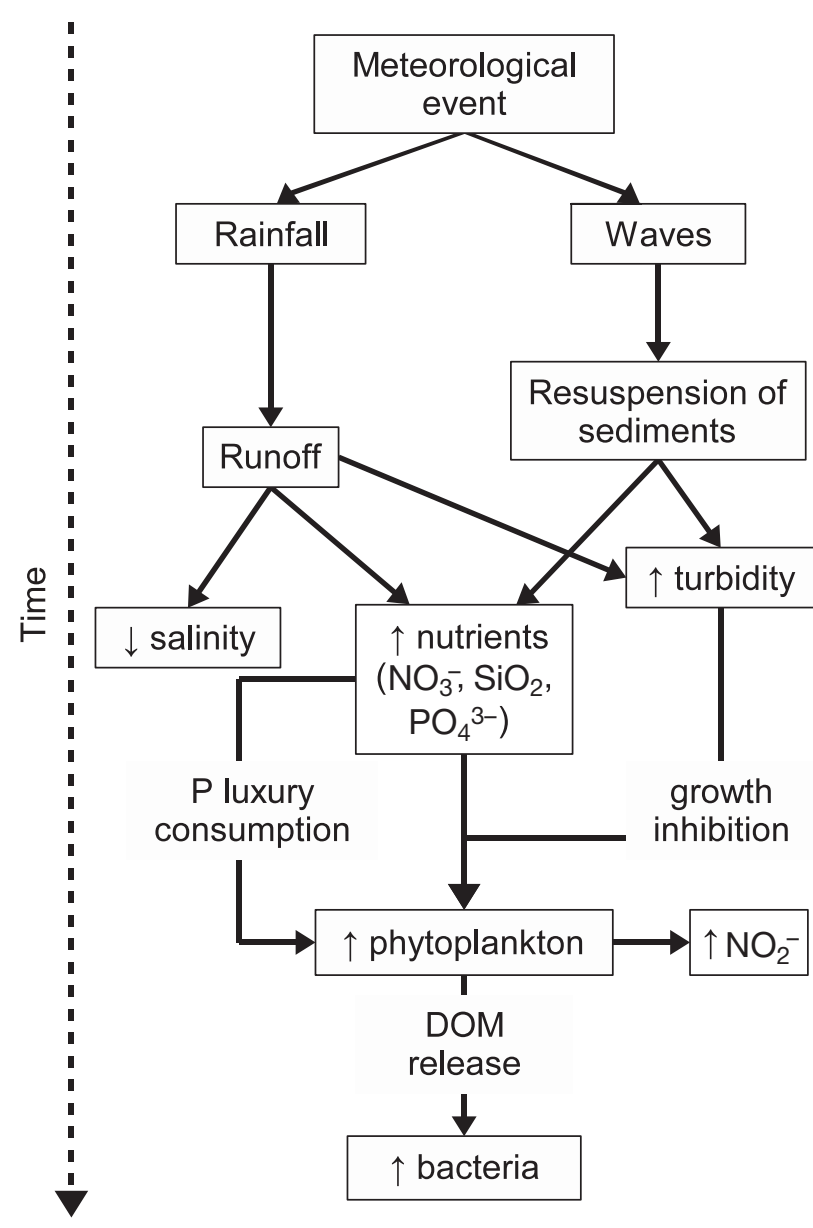

Fig. 9. Hypothetical sequence of responses to meteorological and hydrological events in Blanes Bay

no significant cross correlations arose between phosphate concentration and any of the episodic forcing parameters, by contrast to what happened with $\mathrm{NO}_{3}{ }^{-}$ and $\mathrm{SiO}_{2}$. We will further discuss this issue later, using the data from the 2003 to 2004 period.

Bacteria responded after chl $a$ and only weakly. There was no correlation at lag 0 between river discharge and bacterial concentration. Vaqué et al. (1997) related the bacterial abundances in Blanes Bay with the allochthonous input of dissolved organic matter from runoff flushing after rainstorms. This is consistent with the high negative correlations found between salinity and bacterial and HNF counts (Table 1). However, the several days of lag in significant cross correlation between river discharge and bacteria suggest that bacteria would be growing on newly produced organic matter, rather than on terrestrial or sedimentderived detritus. Given the time resolution of our analyses, however, we cannot rule out a quick $(<7 \mathrm{~d})$ response of bacteria to terrestrial dissolved organic matter input. Indeed, Grémare et al. (2003), in another
NW Mediterranean bay, found an immediate response of bacterial biomass and production to the increase in organic and inorganic nutrient concentrations caused by sediment resuspension after a severe storm. In their study, phytoplankton did not respond to this nutrient input in terms of biomass. They concluded that phytoplankton could not benefit from the increased nutrient concentrations because resuspension caused light limitation, and bacteria exhausted nutrients long before the sedimentation of resuspended material brought the water column back to phytoplankton-growing conditions. As discussed earlier, we observed the response of chl a to occur slightly after the signal in turbidity, suggesting that there could be some light limitation. Nevertheless, there was a response in phytoplankton, which implies that bacterioplankton did not outcompete phytoplankton. This suggests either that the light limitation was not strong or long enough, or that the short-term response of bacterioplankton was not as intense as that in the study by Grémare et al. (2003). Such a relatively mild response of bacterioplankton could be explained either by a top-down or bottomup control. At least for the period between June 2003 and February 2004, there was a weakly significant correlation between bacteria and HNF, which points to a strong link between them. On the other hand, bacteria could be limited, not by inorganic phosphorous, but rather by dissolved organic nutrients, if the allochthonous material is poor in organic matter. Indeed, the amount of organic material in the sandy sediments of Blanes Bay is < 1.4 \% (Marbà \& Duarte 2001). Unfortunately, no data on the organic content of the runoff were available.

\section{Types of episodic forcing}

Rainfall and high wave events frequently occur nearly simultaneously, as shown by the positive peak with a $3 \mathrm{~d}$ lag in the cross correlation between $\mathrm{SWH}$ and river discharge (data not shown). Thus, both resuspension of sediments and terrestrial runoff are effectively operating quasi-simultaneously. This can be seen by examining the salinity and the $\mathrm{SiO}_{2}$ and $\mathrm{NO}_{3}{ }^{-}$ cross correlograms with SWH and with river discharge (Figs. 5 \& 6). Since wave height does not directly affect salinity, its correlation with SWH must be the result of the correlation between SWH and river discharge. Thus, salinity decreases may be taken as signals of the arrival of freshwater from terrestrial runoff after a storm that implies rainfall and high waves. Note, however, that $\mathrm{SiO}_{2}$ and $\mathrm{NO}_{3}{ }^{-}$have significant correlations with SWH at lags close to 0 . This suggests that there is an effect on nutrient concentrations that precedes the arrival of terrestrial runoff. Thus, both types of forcing 
act together, although it is not easy to assess the relative importance of each one from the present analysis. In general, the importance of both processes will depend on the hydrography of the location, the proximity of rivers and populated areas, and on the type of sediments. In this particular system, terrestrial runoff seems to be the dominant forcing factor, as the correlations with river discharge are far more significant than with SWH. Besides, no correlations were found with wind energy flux, although it should also enhance sediment resuspension. Rossi \& Gili (2005) have previously suggested that terrestrial runoff may be a more important factor than water-column mixing in determining seasonal trends in seston composition at a nearby coastal location. This is not surprising, as Mediterranean coasts are low-energy areas (Guillén et al. 2002), with infrequent long-period waves and relatively low tidal amplitudes (Hopkins 1985). In coastal systems with more regular riverine inputs, or no input at all, and with strong tidal currents and/or 'swell' waves (Ferré et al. 2005), the effect of resuspension is likely to be dominant. Other episodic phenomena that have not been considered here may supplement the picture. For example, in this system there are occasional intrusions of nutrient-rich cold and saline open ocean waters facilitated by the presence of the submarine Blanes Canyon (Masó \& Tintoré 1991), which may also alter the seasonal pattern.

Turbulence generated by winds or waves may be another relevant type of coastal forcing. Wind is the dominant source of mechanical energy input to the upper mixed layer (e.g. Lueck \& Reid 1984), particularly in the Mediterranean Sea, where tides are comparatively unimportant (Hopkins 1985). As such, winddriven turbulence may be expected to have an important impact on the coastal osmotrophic plankton, either by increasing sediment resuspension and/or nutrient diffusivities from the sediment (Dade 1993) or by accelerating relevant processes at small scales (e.g. Peters \& Marrasé 2000). We used the wind energy flux (Eq. 2) as a proxy for turbulence intensity. The lack of significant correlations with wind energy flux suggests that the system does not strongly respond to winddriven turbulence. Despite the shallowness of the sampling site, resuspension of sediments is unlikely to occur directly through wind-driven turbulence, because winds at this location are relatively weak (Guadayol \& Peters 2006). Waves play a more important role, and the highest waves occur with easterly storms, because of the longer fetch, and are not necessarily associated with local winds (for example, the event in December 2003; Fig. 2). Northerly winds, which are prevalent in the zone particularly in autumn and can be relatively strong (Guadayol \& Peters 2006), may not generate sufficiently large waves. Other small-scale effects of turbulence on organisms are either not important when compared to the effects of nutrient fertilization or operate at scales that cannot be resolved with our data. In order to understand the effect of turbulence, and particularly of small-scale turbulence, it may be necessary to measure turbulence in situ and/or to perform experiments in which turbulence can be used as an isolated experimental factor (Guadayol et al. in press).

\section{Nutrient dynamics}

Some insight into the possible system responses to turbidity and nutrient enrichment events can be gained from the detailed analysis conducted with data between June 2003 and June 2004. The summer of 2003 registered unusual high temperature and low precipitation in Europe (Trenberth et al. 2007), and the wind energy flux was also particularly low (Fig. 2B). As a consequence, the discharge of the La Tordera River at Gauge E89, our proxy for all sources of runoff, was close to 0 (Fig. 2E), and resuspension of nutrients from sediments was likely to be small. This could explain why, during the summer of 2003, the concentrations of nutrients were low when compared to those measured during the rest of the year, and well below threshold values for the nutrient uptake limitation of phytoplankton (Justić et al. 1995). Between June and September 2003, Pinhassi et al. (2006) found the highest response of heterotrophic bacteria to nutrient addition for the period, suggesting strong nutrient limitation. In addition, only during these months, did they find a change in the composition of bacterioplankton as a response to nutrient enrichment, implying that the bacterial assemblage was well adjusted to the prevailing low nutrient conditions. In these oligotrophic conditions the microbial food web dominated, as suggested by the strong coupling between bacterial and HNF concentrations. The higher ammonium concentration indicates a preponderance of recycling processes over new production, or that ammonium is the dominant form of anthropogenic nitrogen input in summer in Blanes Bay (Duarte et al. 2000).

In the NW Mediterranean, high sea surface temperatures in summer are usually followed by heavy rainfall events in autumn (Llasat \& Puigcerver 1997). Thus, the second part of the period was characterised by several heavy rainstorms. From October 2003 to June 2004 there were at least 6 major meteorological events that implied high $\mathrm{SWH}$, precipitation and river discharge (Fig. 2). The values of $\mathrm{NO}_{3}{ }^{-}$and $\mathrm{SiO}_{2}$ measured in the first samplings after the more intense events were maxima (Fig. 7), whereas the Secchi disk depths were minima (Fig. 3C), in agreement with the results of 
cross-correlation analyses. Among the samples collected after meteorological events, May 2004 was the only period in which no local maxima in $\mathrm{NO}_{3}{ }^{-}$and $\mathrm{SiO}_{2}$ were detected. This could partly be explained by the time that had passed between the event and the sampling (about $3 \mathrm{wk}$ ), and also by the relatively high concentration of diatoms, which could easily have depleted the nutrients by the time of sampling. Also, in agreement with the correlations, the concentration of $\mathrm{PO}_{4}{ }^{-}$did not show an overall clear response to meteorological events, although it steadily increased after November (Fig. 7), suggesting an allochthonous input. The dynamics of chl a were less clearly related to the events of river discharge and SWH during this period, but they were very significantly correlated to $\mathrm{NO}_{3}{ }^{-}$and $\mathrm{SiO}_{2}$ concentrations. In the October 2003 sampling, which was performed immediately after a strong meteorological episode, no increase in chl a was observed although nutrients were high. A change in the community was, however, observed after this event, as diatoms became, for the first time in the period, dominant in the osmotrophic community (Fig. 8A). This shows first that the response of the phytoplankton community may involve changes in composition and structure, and, second, that a detectable response in terms of biomass to the addition of nutrients is not immediate. In other cases, as for example in the December 2003 and May 2004 samplings, done several days after meteorological episodes, chl a maxima were observed.

Thus, between June 2003 and June 2004, the system experienced relative eutrophication. Phosphate, chl a and bacterial concentrations tended to increase during this period. The episodic inputs of nutrients from terrestrial runoff and resuspension determined phytoplankton succession, pushing the system from an oligotrophic state, dominated by the microbial food web and heterotrophic processes, to a more eutrophic state, dominated by diatoms. In the first part of the period, during the summer of 2003, no meteorological events occurred, and the system was apparently deficient in phosphorus $\left(\mathrm{N}: \mathrm{P}>16, \mathrm{PO}_{4}{ }^{3-}<0.1 \mu \mathrm{M}\right.$; Pinhassi et al. 2006, Guadayol et al. in press). The increase in the frequency and intensity of meteorological events starting with the storm in October 2003 determined the concentration of phytoplankton and especially of diatoms. Runoff and sediment resuspension episodically provided $\mathrm{SiO}_{2}$ and $\mathrm{NO}_{3}{ }^{-}$, and likely $\mathrm{PO}_{4}{ }^{3-}$ too. However, in contrast with $\mathrm{NO}_{3}{ }^{-}$and $\mathrm{SiO}_{2}, \mathrm{PO}_{4}{ }^{3-}$ remained relatively invariant after episodic supplies by runoff or by resuspension, although it steadily increased. As a consequence, towards the end of the period, the limiting nutrients were $\mathrm{N}$ and $\mathrm{Si}(\mathrm{Si}<2 \mu \mathrm{M}, \mathrm{N}<1 \mu \mathrm{M}, \mathrm{Si}: \mathrm{N}<5$, $\mathrm{N}: \mathrm{P}<5$; Justić et al. 1995).

Chl a was found to be positively related to $\mathrm{NO}_{3}{ }^{-}$and $\mathrm{SiO}_{2}$, but not to $\mathrm{PO}_{4}{ }^{3-}$ (Table 1). The cross-correlation analysis did not show a response of $\mathrm{PO}_{4}{ }^{3-}$ to either SWH or river discharge (Figs. $5 \& 6$ ), unlike $\mathrm{NO}_{3}{ }^{-}$and $\mathrm{SiO}_{2}$. On the other hand, TP and POP were significantly correlated with Secchi depth, chl $a$ and $\mathrm{NO}_{3}{ }^{-}$, whereas TN and PON were unrelated to any indicator of allochthonous input (Table 1). This suggests that the dominant $P$ input was either in particulate form (Benitez-Nelson 2000) or dissolved $\mathrm{PO}_{4}{ }^{3-}$ that was rapidly depleted by phosphorus-limited osmotrophs through luxury consumption after an episodic input in P. In the latter case, TP or POP would be better indicators of phosphorus dynamics, because any input of $\mathrm{PO}_{4}{ }^{3-}$ would be quickly consumed and therefore difficult to detect with our field sampling scheme. In a series of microcosm experiments with turbulence and nutrient enrichment done during the extended analysis period (Guadayol et al. in press), the dissolved inorganic N:P ratios increased during the incubations in the enriched treatments, except in the last 3 experiments (April to June 2004), when it decreased. Furthermore, the $\mathrm{PO}_{4}{ }^{3-}$ concentration measured $2 \mathrm{~h}$ following the experimental addition was always lower than that expected from nutrient addition, supporting the hypothesis of luxury P consumption. All this additional information backs the idea of a general $P$ deficiency, which is the usual situation in the Mediterranean (e.g. Krom et al. 1991), even though common criteria for limitation (Justic et al. 1995) did not show a dominant limiting nutrient.

An unexpected result of the present study is the strong negative relationship between total diatom biomass and $\mathrm{Si}: \mathrm{N}$ ratios $\left(\mathrm{r}_{\mathrm{s}}=-0.94, \mathrm{p}<0.001, \mathrm{n}=13\right)$. This is puzzling, because there is no significant relationship with silicate or nitrogen (Table 1 ). The relationship with phosphate was strong $\left(\mathrm{r}_{\mathrm{s}}=0.60, \mathrm{p}=0.032, \mathrm{n}=13\right)$; however, it was non-significant after testing the multiple hypotheses (Table 1). The correlation between diatoms and $\mathrm{Si}$ : $\mathrm{N}$ could be partly explained by seasonal changes in the stoichiometry of terrestrial inputs, following agricultural and tourism land-use practices (Duarte et al. 1999, Chattopadhyay et al. 2005). Alternatively, the $\mathrm{Si} \mathrm{N}$ ratio could be a function of the amount of diatoms in relation to other groups of phytoplankton. The Si:N ratio for marine diatoms is around 1:1 (Brzezinski 1985). However, diatoms have been seen to grow even at limiting $\mathrm{Si}$ concentrations, whereas, at low phosphate concentrations, they are outcompeted by flagellated algae (Egge 1998). In May and June 2004, when $\mathrm{PO}_{4}{ }^{3-}$ was at its highest concentrations, diatoms were dominant in Blanes Bay regardless of Si:N ratios < 0.5 and low Si and N concentrations $(<2 \mu \mathrm{M}$; Justić et al. 1995). While $\mathrm{N}$ is taken up by all phytoplankton, Si is only significantly used by diatoms. Therefore, the overall relative consumption of Si compared to $\mathrm{N}$ will change with the relative abundance of diatoms present. This shows also that at least some 
diatom species may sustain high populations at very low Si conditions.

\section{Concluding remarks}

In summary, the cross-correlation analyses objectively detected responses of several coastal parameters to types of forcing characterised by their episodic nature, that is, terrestrial runoff, precipitation and waves. Detailed examination of a period sampled more exhaustively supported the conclusions derived from the cross-correlation analyses, and further indicated the importance of these meteorological episodes in determining the species composition and size structure of the community. In the future, such analyses should become even more robust as higher frequency biogeochemical data from automated stations becomes routinely available. Furthermore, the use of such stations promises to help unveil short-term dynamics that, at least in coastal systems, seem to be as important as seasonal dynamics. In Blanes Bay, meteorological episodes triggered phytoplankton responses, through nutrient enrichment. Increases in bacterial abundance were also found, but they were delayed with respect to phytoplankton, which indicates that they were based on the organic matter released by phytoplankton. Thus, meteorological events involving nutrient inputs push the system towards autotrophy in Blanes Bay.

Understanding how and how much the coastal planktonic community responds to quick and intense disturbances is of particular relevance in scenarios of increased frequency and intensity of severe meteorological events (Trenberth et al. 2007). Indeed, an increase in extreme rainfall events in the NW Mediterranean has already been reported, while there has been a decrease in the yearly accumulated precipitation (Alpert et al. 2002). Besides, during the last century, the increment in human activity and population has altered the composition and increased the amounts of nutrient load derived from freshwater inputs, particularly in the Mediterranean (Vollenweider et al. 1996).

Whenever these episodic perturbations imply an input of allochthonous material, situations in which algae and bacteria compete for new nutrients may appear (Bratbak \& Thingstad 1985). The outcome of this competition will determine whole-ecosystem metabolism: if primary production dominates, the expected organic matter exported by sedimentation is potentially higher than in a situation dominated by the microbial food web. In general, turbidity, which hinders phytoplankton growth, and the input of organic matter, which favours bacterial growth, will be crucial for determining whether a particular coastal system becomes more autotrophic or more heterotrophic in response to a par- ticular meteorological or hydrographic event. Hence, short-term variability in abiotic forcing must be taken into account when interpreting trends in biological activities in coastal ecosystems, even at seasonal scales (e.g. Seymour et al. 2005). The results of the present and other in situ studies (e.g. Nogueira et al. 2000, Grémare et al. 2003, Rossi \& Gili 2005) show that the episodic nature of terrestrial runoff and of mechanical energy forcing is a key factor for understanding the dynamics of coastal planktonic communities.

Acknowledgements. The present study was supported by the EU Project NTAP (EVK3-CT-2000-00022) and by the Spanish projects VARITEC (REN2003-08071-C02-01/MAR) and TURFI (REN2002-01591/MAR). The Blanes Bay Microbial Observatory has been supported by the EU Project BASICS (EVK3-CT-2002-00078) and by the Spanish Projects ESTRAMAR (CTM2004-12631/MAR) and MODIVUS (CTM200504795/MAR). O.G. had a Spanish CSIC-I3P fellowship sponsored by INNOVA Oceanografía Litoral, S.L. We thank O. López for his support. The Catalan Meteorological Service provided meteorological data from Malgrat de Mar, the Meteorological and Oceanographic Instrumental Net provided wave height data, and the Catalan Water Agency provided data on La Tordera River discharge. Juan Albiol provided sampling assistance with his boat 'Margarita'. We thank V. Balagué, C. Cardelús, J. Felipe and I. Forn for their help with field work and sample processing. R. Ventosa processed the inorganic nutrients. We also thank M. Segura-Noguera and S. Vallina for inspiring discussions and 2 anonymous reviewers and Dr. Savidge for helpful comments on the manuscript. This is an ELOISE (European Land Ocean Interaction Studies) contribution.

\section{LITERATURE CITED}

Agawin NSR, Duarte CM, Agustí S (1998) Growth and abundance of Synechococcus sp. in a Mediterranean Bay: seasonality and relationship with temperature. Mar Ecol Prog Ser 170:45-53

Alonso-Sáez L, Vázquez-Domínguez E, Cardelús C, Pinhassi $\mathrm{J}$ and others (2008) Factors controlling the year-round variability in carbon flux through bacteria in a coastal marine system. Ecosystems 11:397-409

Alpert P, Ben-Gai T, Baharad A, Benjamini Y and others (2002) The paradoxical increase of Mediterranean extreme daily rainfall in spite of decrease in total values. Geophys Res Lett 29:311-314

Arnau P, Liquete C, Canals M (2004) River mouth plume events and their dispersal in the northwestern Mediterranean Sea. Oceanography 17:22-31

Benitez-Nelson CR (2000) The biogeochemical cycling of phosphorus in marine systems. Earth Sci Rev 51:109-135

Benjamini Y, Hochberg Y (1995) Controlling the false discovery rate: a practical and powerful approach to multiple testing. J R Stat Soc B 57:289-300

Bertilsson S, Berglund O, Karl DM, Chisholm SW (2003) Elemental composition of marine Prochlorococcus and Synechococcus: implications for the ecological stoichiometry of the sea. Limnol Oceanogr 48:1721-1731

Bjørnsen PK (1986) Automatic determination of bacterioplankton biomass by image analysis. Appl Environ Microbiol 51:1199-1204 
Bratbak G, Thingstad TF (1985) Phytoplankton-bacteria interactions: An apparent paradox? Analysis of a model system with both competition and commensalism. Mar Ecol Prog Ser 25:23-30

Brzezinski MA (1985) The Si:C:N ratio of marine diatoms: interspecific variability and the effect of some environmental variables. J Phycol 21:347-357

Cebrián J, Duarte CM, Pascual J (1996) Marine climate on the Costa Brava (northwest Mediterranean) littoral. Pub Espec Inst Esp Oceanogr 22:9-21

Chatellier L, Fitzpatrick J (2005) Spatio-temporal correlation analysis of turbulent flows using global and single-point measurements. Exp Fluids 38:563-575

Chattopadhyay S, Rani LA, Sangeetha PV (2005) Water quality variations as linked to landuse pattern: a case study in Chalakudy river basin, Kerala. Curr Sci 89:2163-2169

Cloern JE (1987) Turbidity as a control on phytoplankton biomass and productivity in estuaries. Cont Shelf Res 7: 1367-1381

> Cloern JE (1996) Phytoplankton bloom dynamics in coastal ecosystems: a review with some general lessons from sustained investigation of San Francisco Bay, California. Rev Geophys 34:127-168

Collos Y (1998) Nitrate uptake, nitrite release and uptake, and new production estimates. Mar Ecol Prog Ser 171:293-301

Cotner JB (2000) Intense winter heterotrophic production stimulated by benthic resuspension. Limnol Oceanogr 45: 1672-1676

Dade WB (1993) Near bed turbulence and hydrodynamic control of diffusional mass-transfer at the sea-floor. Limnol Oceanogr 38:52-69

> de Madariaga I, Gonzalez-Azpiri L, Villate F, Orive E (1992) Plankton responses to hydrological changes induced by freshets in a shallow mesotidal estuary. Estuar Coast Shelf Sci 35:425-434

Duarte CM, Agustí S, Kennedy H, Vaqué D (1999) The Mediterranean climate as a template for Mediterranean marine ecosystems: the example of the northeast Spanish littoral. Prog Oceanogr 44:245-270

> Duarte CM, Agustí S, Agawin NSR (2000) Response of a Mediterranean phytoplankton community to increased nutrient inputs: a mesocosm experiment. Mar Ecol Prog Ser 195:61-70

Duarte CM, Agustí S, Vaqué D (2004) Controls on planktonic metabolism in the Bay of Blanes, northwestern Mediterranean littoral. Limnol Oceanogr 49:2162-2170

Egge JK (1998) Are diatoms poor competitors at low phosphate concentrations? J Mar Syst 16:191-198

Estrada M, Vives F, Alcaraz M (1985) Life and the productivity of the open sea. In: Margalef R (ed) Western Mediterranean. Pergamon Press, Oxford, p 148-197

Ferré B, Guizien K, Durrieu de Madron X, Palanques A, Guillén J, Grémare A (2005) Fine-grained sediment dynamics during a strong storm event in the inner-shelf of the Gulf of Lion (NW Mediterranean). Cont Shelf Res 25: $2410-2427$

> Gargett AE (1989) Ocean turbulence. Annu Rev Fluid Mech 21:419-451

Garstecki T, Wickham SA, Arndt H (2002) Effects of experimental sediment resuspension on a coastal planktonic microbial food web. Estuar Coast Shelf Sci 55:751-762

- Gasol JM, del Giorgio PA (2000) Using flow cytometry for counting natural planktonic bacteria and understanding the structure of planktonic bacterial communities. Sci Mar 64:197-224

> Grémare A, Amoroux JM, Cauwet G, Charles F and others (2003) The effects of a strong winter storm on physical and biological variables at a shelf site in the Mediterranean. Oceanol Acta 26:407-419

Guadayol Ò, Peters F (2006) Analysis of wind events in a coastal area: a tool for assessing turbulence variability for studies on plankton. Sci Mar 70:9-20

Guadayol Ò, Marrasé F, Peters F, Berdalet E, Roldán C, Sabata A (in press) Responses of coastal osmotrophic planktonic communities to simulated events of turbulence and nutrient load throughout a year. J Plankton Res doi: fbp019v1

Guillén J, Jiménez JA, Palanques A, Gracia V, Puig P, SánchezArcilla A (2002) Sediment resuspension across a microtidal, low-energy inner shelf. Cont Shelf Res 22:305-325

Hansen HP, Koroleff F (1999) Determination of nutrients. In: Grasshoff K, Kremling K, Ehrhardt M (eds) Methods of seawater analyses. Wiley-VCH, Weinheim, p 161-228

> Hillebrand H, Durselen CD, Kirschtel D, Pollingher U, Zohary $\mathrm{T}$ (1999) Biovolume calculation for pelagic and benthic microalgae. J Phycol 35:403-424

Hopkins TS (1985) Physics of the sea. In: Margalef R (ed) Western Mediterranean. Pergamon Press, Oxford, p 100-125

Jenkins GM, Watts DG (1968) Spectral analysis and its applications. Holden-Day, San Francisco

Justić D, Rabalais NN, Turner RE, Dortch Q (1995) Changes in nutrient structure of river-dominated coastal waters: stoichiometric nutrient balance and its consequences. Estuar Coast Shelf Sci 40:339-356

Krom MD, Kress N, Brenner S, Gordon LI (1991) Phosphorus limitation of primary production in the eastern Mediterranean. Limnol Oceanogr 36:424-432

> Llasat MC, Puigcerver M (1997) Total rainfall and convective rainfall in Catalonia, Spain. Int J Climatol 17:1683-1695

Lomas MW, Lipschultz F (2006) Forming the primary nitrite maximum: Nitrifiers or phytoplankton? Limnol Oceanogr 51:2453-2467

Lucea A, Duarte CM, Agustí S, Kennedy H (2005) Nutrient dynamics and ecosystem metabolism in the Bay of Blanes (NW Mediterranean). Biogeochemistry 73:303-323

Lueck R, Reid R (1984) On the production and dissipation of mechanical energy in the ocean. J Geophys Res C 89: 3439-3445

Marbà N, Duarte CM (2001) Growth and sediment space occupation by seagrass Cymodocea nodosa roots. Mar Ecol Prog Ser 224:291-298

Margalef R (1978) Life-forms of phytoplankton as survival alternatives in an unstable environment. Oceanol Acta 1:493-509

Masó M, Tintoré J (1991) Variability of the shelf water off the northeast Spanish coast. J Mar Syst 1:441-450

Montagnes DJS, Berges JA, Harrison PJ, Taylor FJR (1994) Estimating carbon, nitrogen, protein, and chlorophyll a from volume in marine phytoplankton. Limnol Oceanogr 39:1044-1060

Mura MP, Agustí S, Cebrián J, Satta MP (1996) Seasonal variability of phytoplankton biomass and community composition in Blanes Bay. Pub Espec Inst Esp Oceanogr 22:23-29

> Nogueira E, Ibanez F, Figueiras FG (2000) Effect of meteorological and hydrographic disturbances on the microplankton community structure in the Ria de Vigo (NW Spain). Mar Ecol Prog Ser 203:23-45

Ogilvie BG, Mitchell SF (1998) Does sediment resuspension have persistent effects on phytoplankton? Experimental studies in three shallow lakes. Freshw Biol 40:51-63

Olden JD, Neff BD (2001) Cross correlation bias in lag analysis of aquatic time series. Mar Biol 138:1063-1070

Peters F, Marrasé C (2000) Effects of turbulence on plankton: an overview of experimental evidence and some theoretical considerations. Mar Ecol Prog Ser 205:291-306 
Pinhassi J, Gómez-Consarnau L, Alonso-Sáez L, Sala MM, Vidal M, Pedrós-Alió C, Gasol JM (2006) Seasonal changes in bacterioplankton nutrient limitation and their effects on bacterial community composition in the NW Mediterranean Sea. Aquat Microb Ecol 44:241-252

Reiter ER (1975) Handbook for forecasters in the Mediterranean. Weather Phenomena of the Mediterranean Basin, Part 1: general description of the meteorological processes. Environmental Prediction Research Facility, Naval Postgraduate School, Monterey, CA

Rossi S, Gili JM (2005) Composition and temporal variation of the near-bottom seston in a Mediterranean coastal area. Estuar Coast Shelf Sci 65:385-395

Seymour JR, Seuront L, Mitchell JG (2005) Microscale and small-scale temporal dynamics of a coastal planktonic microbial community. Mar Ecol Prog Ser 300:21-37

Trenberth KE, Jones PD, Ambenje P, Bojariu R and others (2007) Observations: surface and atmospheric climate change. In: Solomon S, Qin D, Manning M, Chen Z and others (eds) Climate change 2007: the physical science basis. Contribution of Working Group I to the 4th assessment of the Intergovernmental Panel on Climate Change. Cambridge University Press, Cambridge, p 235-336

Vaqué D, Blough HA, Duarte CM (1997) Dynamics of ciliate abudance, biomass and community composition in an oligotrophic coastal environment (NW Mediterranean). Aquat Microb Ecol 12:71-83

Editorial responsibility: Graham Savidge, Portaferry, UK
Vaulot D, Partensky F, Neveux J, Mantoura RFC, Llewellyn CA (1990) Winter presence of prochlorophytes in surface waters on the northwestern Mediterranean Sea. Limnol Oceanogr 35:1156-1164

Verity PG, Robertson CY, Tronzo CR, Andrews MG, Nelson JR, Sieracki ME (1992) Relationships between cell volume and the carbon and nitrogen content of marine photosynthetic nanoplankton. Limnol Oceanogr 37:1434-1446

Vidondo B, Prairie YT, Blanco JM, Duarte CM (1997) Some aspects of the analysis of size spectra in aquatic ecology. Limnol Oceanogr 42:184-192

Vila-Costa M, Pinhassi J, Alonso C, Pernthaler J, Simó R (2007) An annual cycle of dimethylsulfoniopropionate-sulfur and leucine assimilating bacterioplankton in the coastal NW Mediterranean. Environ Microbiol 9: 2451-2463

Vollenweider RA, Rinaldi A, Viviani R, Todini E (1996) Assessment of the state of eutrophication in the Mediterranean Sea. MAP Technical Reports Series, UNEP/FAO, Athens

Wainright SC (1987) Stimulation of heterotrophic microplankton production by resuspended marine sediments. Science 238:1710-1712

Yentsch CS, Menzel DW (1963) A method for the determination of phytoplankton chlorophyll and phaeophytin by fluorescence. Deep-Sea Res 10:221-231

Submitted: August 26, 2008; Accepted: January 20, 2009 Proofs received from author(s): March 30, 2009 